\title{
日本海側冬季雷雲下に㧈ける地上電界極性の 地域分布の推定
}

$\begin{array}{cccccc}\text { 正 員 櫻 } & \text { 野 } & \text { 仁 } & \text { 志 } & \text { (石川高専) } \\ \text { 准 員 松 } & \text { 原 } & \text { 亮 } & \text { 滋 } & \text { (名古屋大) } \\ \text { 准 員 村 } & \text { 下 } & \text { 直 } & \text { 久 } & \text { (名古屋大) } \\ \text { 正 員 鬼 } & \text { 頭 } & \text { 幸 生 } & \text { (名古屋大) }\end{array}$

\section{1.まえがき}

電力供給に支障をきたす原因のうちでは，電力施設 への雷害が大きな比率を占めるに至っている(1)。雷雲 の俩来時にどのような条件で対地雷放電が発生するか を予知できれば，この雷害を防止するという見地から 極めて有効である。著者らによるロケット誘雷実験て 経験されたことであるが，誘雷地点の地上電界が高く ても必ずしも誘雷に成功するとは限らない。すなる ち, 雷雲の広がりおよびロケット発射地点と雷雲との 相対位置などに依存して，誘雷の成否が左右されるこ とが指摘されている(2)。このような結果から，自然に 発生する雷放電についても，その周辺環境までを明ら かにすることは重要と考えられる。

雷雲下の電界は, 雷雲電荷の移動やそれに伴う空間 電荷の発生状況により徐々に変化していく準静電界で ある。雷放電の開始については，雲側か地表側かにお いて電界の局部的ひずみが徐々に高まり，あるレベル を超えたときにりーダが誘発され，場合によっては大 地への放電路が形成されると考えられる。衝撃性の電 界が印加されて，大気の絶縁破壤が生じるのではな い(3)。自然の雷放電の発生環境についての示唆を得る

Presumption of Regional Distribution of the Electric Field Polar ity on the Ground Induced by Winter Thundercloud in Hokuriku District. By Hitoshi Sakurano, Member (Ishikawa College of Technology), Ryoji Matsubara, Associate, Naohisa Murashita, Associate \& Yukio Kito, Member (Faculty of Engineering. Nagoya University).

筢野仁志：正買, 石川工業高等尃門学校電気工学科

松原亮㶌: 准員, 名古屋大学大学院工学研究科博士課程前期課程 (現在, 日立電楾(株) )

村下直久: 准員, 名古屋大学大学院工学研究科搏士課程前期課程 (現在，(株)高岳製作所)

鬼頭幸生：正負，名古屋大学工学部電気学科
一つの手段として，雷雲下における地上電界の地域分 布を把握する必要があると考えた。本論分では，その 第一段階として, 我が国の日本海側浻岸に冬季に獎来 する雷雲によってもたらされる地上電界の極性分布を 対象として，その推定方法を取上げている。

多地点での電界観測の代表例としては, 北陸地方日 本海側に多数の回転セクタ形電界計を配置した航空関 係の観測システムがあり，航空機の安全運航に指針を 与えている。このほかにも，地上電界の多地点観測の 有効性は多く指摘されている(4)。

著者らは，実際に針端コロナ電流測定装置 ${ }^{(5)}$ を使用 して地上電界の多地点観測を行い，その結果から冬季 雷雲下の地上電界極性の地域分布を推定できる方法を 新たに考案した。更に，この方法によって得られた地 上電界極性の地域分布とロケット誘雷の放電路とを関 連づけて考察することによって，人為的な対地雷放電 についてではあるが, 雷放電の進展方向と発生環境と の関連性を初めて指摘した。本推定法は, 冬季に発生 する自然の雷放電の発生環境に適用して特に有効であ り，電力施設の雷害防止対策などを検討するうえで有 用であると思わ机る。ただし，ここで述べようとして いる方法は, 雷雲内の電荷の状況が著しくは変化せ ず，ほぼ直進すると予想される範囲内で，適用が可能 なものである。このような条件は冬季雷はほぼ満足し ているが，激しい熱雷を主体とする夏季雷では吟味を 要する。

著者らが使用した針端コロナ電流測定装置は極めて 簡易で可動部分がなく, 従って大きな電源を必要とし ないなどの特色をもつ反面, 定量的な精度の点では若 干劣る。ここでは, 多地点観測の有効性を指摘するこ とに主眼があり，回転セクタ形電界計のような高級な 器具を多数そろえれば, 更に定量的に良好な成果を得 
るものと思われる。

以下，第 2 章では針端コロ十電流多地点観測の結果 加ら雷雲の移動方向と移動速度を算出する方法につい て，第 3 章では地上電界極性の地域分布の推定結果に ついて，第 4 章ではその地域分布とロケット誘雷放電 路の関係について述べる。

\section{2. 雷雲の移動方向と移動速度の算出}

\section{〈2・1〉 針端コロナ電流多地点観測 著者らは,} 昭和 52 年加ら石川県河北潟干拓地において, 冬季雷 を対象としたロケット誘雷実験に参加し(6), そのなか で針端コロナ電流の多地点観測を妢担してきた。観測 期間は表 1 に示されるように毎年度 11 月下旬から約 1 箇月間である。観測方法杖よび観測地点の配置につ いては文献 (2)に記述するところであるが, 概要は次

表 1 針端コロナ電流の多地点観測期間

Table 1. Period of the observation of the point discharge current at multi sites.

\begin{tabular}{c|c}
\hline 年 度 & 倠貺間 \\
\hline 61 & $11 / 30 \sim 12 / 26$ \\
\hline 60 & $11 / 30 \sim 12 / 16$ \\
\hline 59 & $11 / 20 \sim 12 / 20$ \\
\hline 58 & $11 / 22 \sim 12 / 18$ \\
\hline 57 & $11 / 25 \sim 12 / 18$ \\
\hline
\end{tabular}

のとおりである。電極は直径 $0.3 \mathrm{~mm}$ のニッケル電極 で先端を半球状に研磨してある。これを地上 $5 \mathrm{~m} に$ 支持し下端を $10 \mathrm{k} \Omega て ゙$ 接地して,この電圧降下でコ ロナ電流を検出する。記録には自動平衡方式のペンレ コーダを用いており，針端コロナ電流の平均值が記録 されるが,ここでは「針端コロナ電流波形」と記述す ることにする。河北潟干拓地付近の概略の地図と，そ こにおける観測点の位置を図1に示す。

各地点における針端コロナ電流波形の測定結果の一 例を図 2 に示す。波形は測定地点 $K, L, M, N, P, Q$

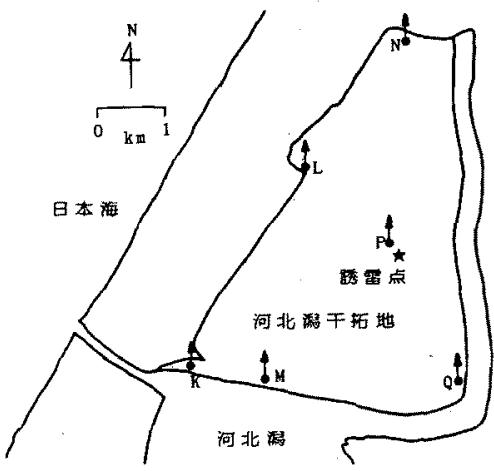

図 1 針端コロナ電流の観測位㯰 (昭和 59 年)

Fig. 1. Observation sites of the point discharge current.

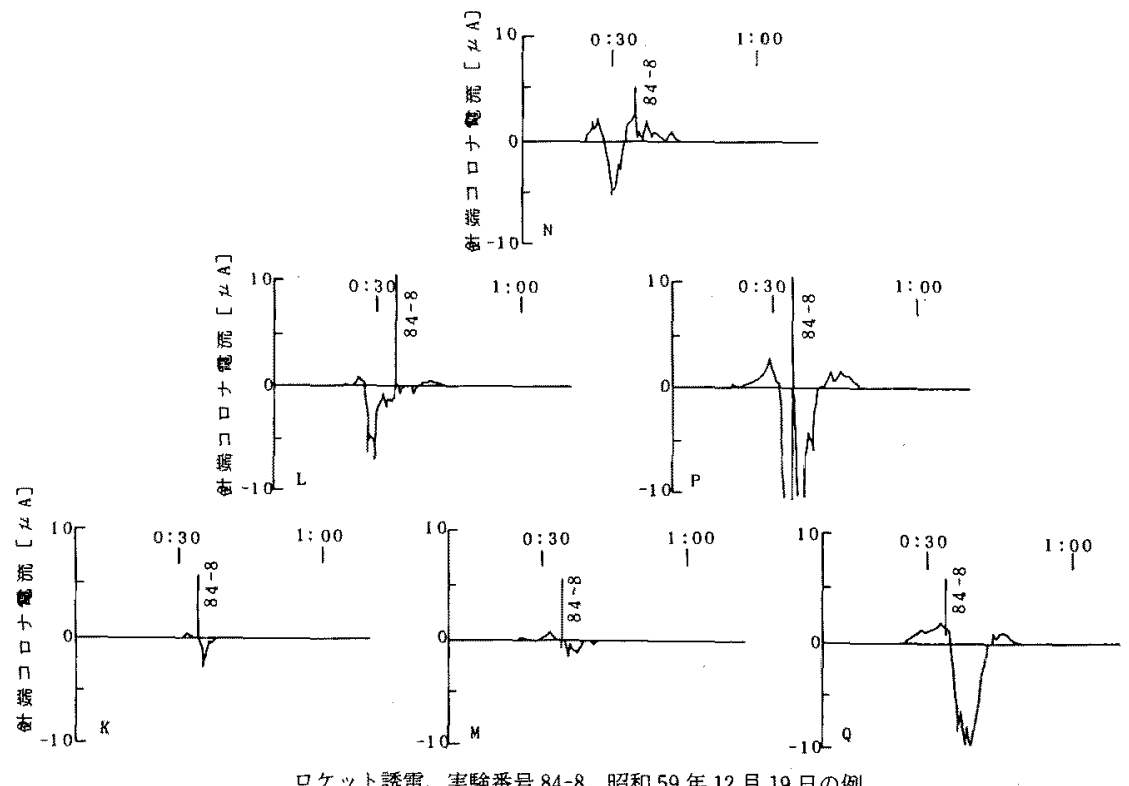

ロケット誘雷, 実験番号 84-8, 昭和 59 年 12 月 19 日の例

図 2 各観測地点での針端コロナ電流波形

Fig. 2. Waveforms of the point discharge current at each observation site before and after the triggered lightning. 
の各位置にだいたい対応させて示した。各地点の針端 コロナ電流波形には時間的な遅れをもって類似した波 形が明らかに読取れ，河北潟干拓地程度の範囲なら代 雷雲の状況があまり激しく変化することなく移動して いることに対応する。この特徵は, 日本海側冬季雷で は非常に顕著に見られる。日本海側冬季雷の場合, 雷 雲は海上で発達し陸へと移動する(7)。従って, 河北潟 干拓地程度の移動距離（約 $5 \mathrm{~km}$ ）では雷雲内の電荷 配置はさほど変化しないと考えられる。このような波 形上の特徵から後述のようなデータ処理を行うことに より, 雷雲の移動方向, 移動速度を算出することがで きる。各年度の誘雷地点は多少の移動があっても，だ いたいこの地区の中心付近で図 $1 の P$ 点の近傍であ る。コロナ電流の大きさは応答周波数の上限 $1 \mathrm{~Hz}$ 程 度のペンレコーダで記録しているにもかかわらず，誘 雷時点あるいは自然雷の発生時点には，いずれの測定 地点でもパルス状の変化が認められ，時刻合せに役立 つ。そのような現象に基づいて，後に示す図 5 の電界 分布の地理的，時間的対応を確定している。

\section{〈2-2〉 雷雲の移動方向と移動速度の算出方法}

測定地点のうちで任意の三地点での針端コロナ電流 観測結果より, 雷雲の移動方向と移動速度を以下に示 す方法で算出した。

図 3 において，O,A,B を針端コロナ電流観測地点 とする。 $O A, O B$ の距離を $a, b$ とし, 両者の成方角 を $\theta$ とする。雷雲 $M$ が矢印のように, 移動方向 $\alpha$ (OA を基準に左回りを正とする)，速度 $v$ で移動す ると仮定する。この雷雲電荷は必ずしも算一極性とは 限らないが, 電荷群の総合された結果として, 地点 $O, A, B$ の電界が正または負の值となっている。最も 高くなるのは，図 3 を参照すればそれぞれ時刻 $t=0$, $t=t_{A}, t=t_{B}$ に扔いて各観測点に最も近い距離に雷雲

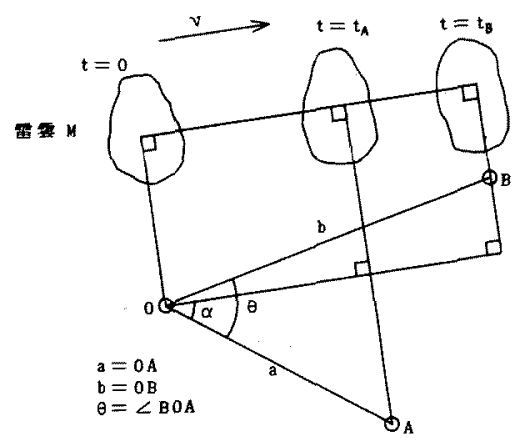

図 3 雷雲の移動方向と移動速度の算出

Fig. 3. Calculation of a moving course and a moving speed of the thundercloud.

電学論 B， 109 巻 8 号, 平成元年
が来たときとなる。移動速度 $v$ を定とすると次式 が成り立つ。

$$
\begin{aligned}
& v t_{A}=a \cos \alpha \\
& v t_{B}=b \cos (\theta-\alpha)
\end{aligned}
$$

(1)式と (2)式より,

$$
\begin{aligned}
& \alpha=\tan ^{-1} \frac{t_{B} a-t_{A} b \cos \theta}{t_{A} b \sin \theta} \\
& v=\frac{a \cos \alpha}{t_{A}}
\end{aligned}
$$

ただし， $t_{A}, t_{B}: O$ 点と $A$ 点および $O$ 点と

$B$ 点の針端コロナ電流波形の対応する極大

値の時間差

〈2・3〉算出結果と吟味 $\quad(3),(4)$ 式加算出 した移動方向と移動速度の結果を，ロケット誘雷に成 功した 4 回の時刻について図 4 に示す。六地点のうち
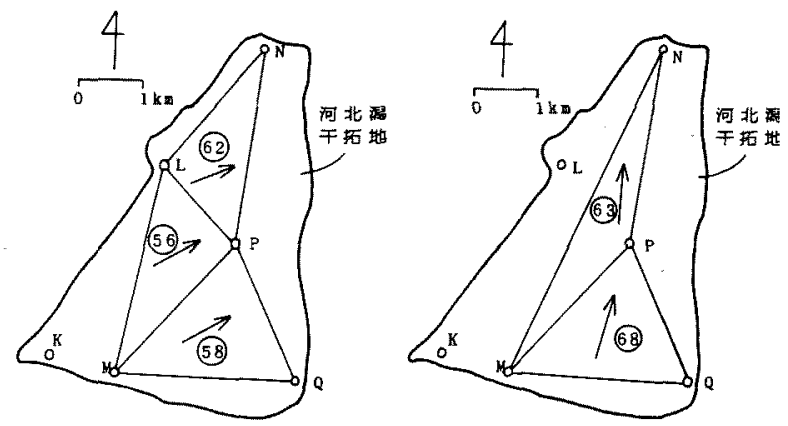

(a) 实要告 84-3 (昭59.12.1,19:28)

b) 実 号 84-7 (昵 $59.12 .17,0 \div 22)$
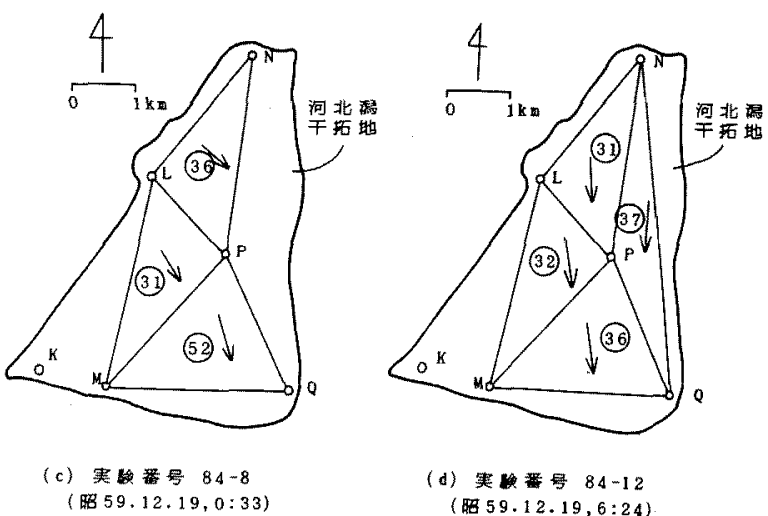

(d) $84-12$

(娟 $59.12 .19,6: 24)$

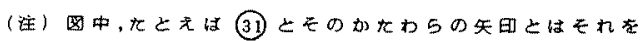

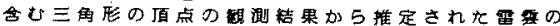

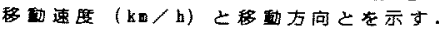

図 4 雷雲の移動方向と移動速度の算出結果 Fig. 4. Calculated results of a moving course and a moving speed of the thundercloud. 
から三地点を複数個〔例えば，(a)図では $\triangle N L P$ ， $\triangle L M P, \triangle P M Q$ の 個 を選んで, それぞれの雷雲 の移動方向（矢印で示す）と移動速度（円内の数値, $\mathrm{km} / \mathrm{h}$ で示す) を算定し，図中に示してある。複数の 三角領域からの結果がある程度一致しているので, 個々に得られた值の算術平均をもって雷雲の移動方向 と移動速度の推定値とした。

一般に, 雲の動きは気象レーダのエコーを連続観測 することによっても広い範囲で知ることができる。冬 季ロケット誘雷実験においては, 金沢地方の気象レー ダの観測から求められた雷雲の移動状況を問い合せ, そのつど実験日誌に記録している。この移動状況は, 主として日本海上から本土沿岸までについてのもので あるが, 冬季の雷雲は季節風の方向に移動し続けるの が通常であるので，河北潟干拓地についても浪深同様 とみなされ，針端コ口十電流から求めた值を吟味する ために用いた。

レーダ観測による結果と針端コロナ電流の多地点観 測による算出結果との比較を昭和 60 年度について表 2 に示す。移動方向は気象レーダに合せて両者とも北 を 0 度として右回りを正としている。レーダ観測の欄 の時刻は電話による問い合せの時刻である。針端コロ ナ電流観測による雷雲の移動方向および速度は記載時 刻の前後 30 分から 1 時間の波形から算出した。

これによると，両者の推定結果はほほ一致してお

表 2 雷雲の移動方向と移動速度について針端 コロナ電流多地点観測による推定とレーダ 観測による推定の比較 (昭和 60 年)

Table 2. Moving courses and speeds of the winter thundercloud estimated by the proposed method and by rader observation.

\begin{tabular}{|c|c|c|c|c|c|c|}
\hline \multirow[b]{2}{*}{ 月日 } & \multicolumn{3}{|c|}{ 針端コロ十晸流観溂による } & \multicolumn{3}{|c|}{ 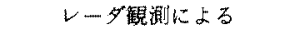 } \\
\hline & 時刻 & $\begin{array}{c}\text { 移動方向 } \\
\text { (DEG) }\end{array}$ & $\begin{array}{c}\text { 移動速度 } \\
(\mathrm{km} / \mathrm{h})\end{array}$ & 時刻 & $\begin{array}{c}\text { 移動方向 } \\
\text { (DEG) }\end{array}$ & $\begin{array}{c}\text { 移動速度 } \\
(\mathrm{km} / \mathrm{h})\end{array}$ \\
\hline \multirow{3}{*}{$12 / 9$} & $2 ; 00$ & 100 & 55 & \multirow{3}{*}{$3: 25$} & \multirow{3}{*}{90} & \multirow{3}{*}{60} \\
\hline & $4: 30$ & 80 & 60 & & & \\
\hline & $5: 00$ & 90 & 40 & & & \\
\hline $12 / 10$ & $24: 00$ & 130 & 45 & $22: 00$ & 不明 & 45 \\
\hline \multirow{2}{*}{$12 / 11$} & \multirow{2}{*}{$21: 00$} & \multirow{2}{*}{65} & \multirow{2}{*}{35} & $20: 40$ & 110 & 40 \\
\hline & & & & $22: 38$ & 110 & 40 \\
\hline $12 / 13$ & $21: 30$ & 70 & 65 & $21: 28$ & 80 & 50 \\
\hline $12 / 14$ & $20: 00$ & 90 & 55 & $21: 50$ & 90 & 60 \\
\hline $12 / 18$ & $2: 00$ & 130 & 50 & $2: 13$ & 130 & 50 \\
\hline
\end{tabular}

注 1) 移動方向は，北を0度として右回りを正としている。

注 2)針端コロ十電流欄では記戴時刻の前後 30 分から1時間の波形か ら方向と速度を推定した。

注 3)レーダ観群闑の時刻は電話で問い合せた時刻であり，誘雷実験日 誌に記入してあるものなすいて記载してある。
り，針端コロナ電流の多地点観測から求めた雷雲の移 動方向と移動速度の算出結果は妥当なものといえる。

\section{3. 地上電界極性の地域分布の推定}

前章の方法で移動方向, 移動速度が求まると, 本章 に述べる作図法により地上電界極性の地域分布が推定 できる。一例として，昭和 59 年 12 月 19 日 0 時 33 分 に誘雷成功した実験 No. 84-8のロケット打上げ直前 の地上電界極性の分布を図 5 に示す。このとき雷雲は 北から右回りに測って 150 度の方向へ $40 \mathrm{~km} / \mathrm{h}$ で移 動していた。

作図方法を $N$ 点について具体的に説明すれば，次 のとおりである。 $N$ 点を通り雷雲の移動方向に直線 $A B$ を描く。これに平行に時間軸 $O T$ を描いて, こ こに $N$ 点にお污る針端コロナ電流波形（図 2 の $N$ 点 参照)を描く。このとき，時間の流れは $O$ から $T$ へ 向かうことに留意する。またここの波形上に時刻 $T_{0}$ にパルスが㒛められる。これは $P$ 点でロケット誘雷 に成功した 0 時 33 分に発生したものである。この種 のパルスは干拓地内の六地点すべてに発生するもの で，時刻合せに利用できる。さて，コロナ電流が正で 持続した期間 $\left(T_{2}-T_{1}\right)$ に移動速度を掛け合せて求め た距離 $B C$ を直線 $A B$ 上にとる。それに次ぐ負の期

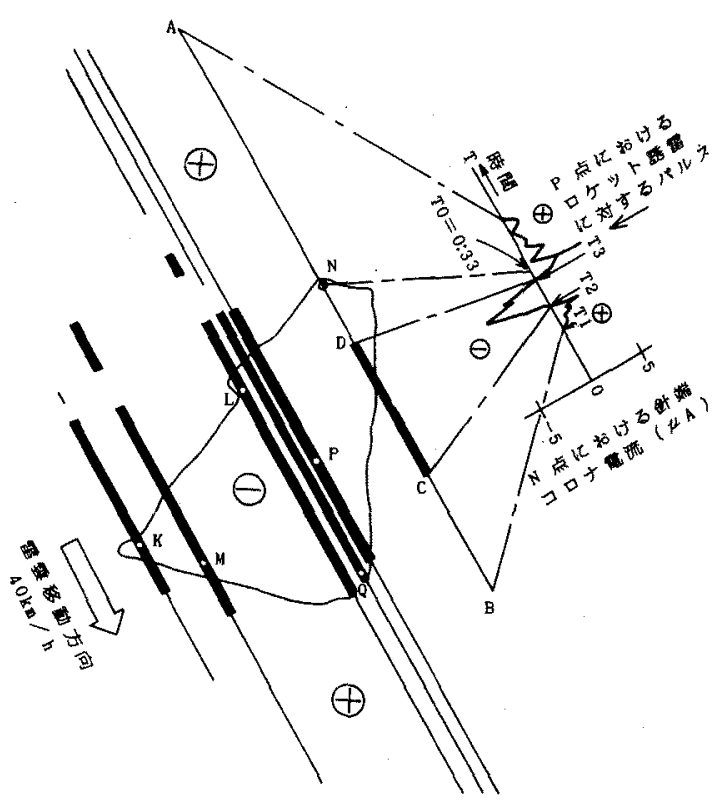

実駼番号 84-8, 昭和59年12月19日, 0:33

図 5 地上電界の地域竹布の推定例

Fig. 5. An estimated example of regional distributions of the electric field on the ground. 
間 $\left(T_{3}-T_{2}\right)$ に対して同様に距離 $C D$ をとる。この $C D$ は線を太くして示してある。このように直線 $A B$ を区切っていく。このような操作を他の観浿点 $K, L$, $M, P, Q$ について行い, 最終的に図 5 を得る。ただ し, 針端コロナ電流が 0 のき（電界強度で約 $1 \mathrm{kV}$ ) $\mathrm{m}$ 以下に相当）は線を引かない。

個々の点について作図したにもかかわらず，図 5 に は地上の電界の極性分布が地図上に浮かび上ってく る。この例では, ロケットを打上げた 0 時 33 分には, 河北潟干拓地程度の大きさの地域が負極性の地上電界 となっており，しばらくはこの行布状態のままで北西 から南東の方向へ推移していくのがよくわかる。

ここでは単に極性だけを表示したが，移動方向上の 電界強度が針端コロナ電流の大きさから概算できれば それを付加することによって，更に有用な地域分布が 得られることとなる。

\section{4. 対地雷放電路と地上電界極性の地域分布 との関連性}

雷放電路の進展の立体的な解析を行うためには，二 方向からのスチール写真が必要となる。自然雷でこの 条件を満たす写真を得るのはなかなか難しいが, 落雷 位置と時刻をあらかじめ設定できるロケット誘雷では 容易である。これまでのロケット誘雷放電に扔いて， その立体解析結果によって放電路の水平面上の進展状 況と垂直面上の進展状況がそれぞれ明らかにされたも のは7例であった ${ }^{(8)}$ 。ここでは, その7例の進展状況 と,さきに求めたような地上電界極性の地域分布との 関連性について述べる。

図 6 は雷放電路の水平面への投影図と地上電界の分 布を重ねて描いたものである。ただし，第 3 章と同様 な地域分布の表示方法をとると見にくくなるので，こ こでは分布領域の概略を太い実線で，その極性を○印 の中にそれぞれ示した。放電路のうち破線で西んだ部 分は片方のスチール写真のみから推定した形状であ る。

同図から，冬季ロケット誘雷における放電路は誘雷 点を含む極性領域の中央部に向かう傾向があると結論 される。例えば，帯状の地上電界の分布をもつ(a), (b)，(e)図においては，放電路は带の中央部に向か う。そのほかの(c), (d), (f)，（g)図ではそれぞ れの極性領域における中央部に向かう傾向が諰められ る。すなわち, 雷雲の中に電荷密度の高い部分が中央 部に存在し, それに向かって誘雷された放電路が進展 していると推定される。

また，(a)，（g)図については雷放電路が垂直方向
に延びるのではなく, 誘雷点から水平距離で $1 \mathrm{~km}$ 以 上にわたって横に進展している。これは, ロケットを 打上げた位置が電荷密度の高い雲の中央部ではなく, 端のほうに偏っていたからであると思われる。特に, (a)図においてはそれが顕著である。逆に, 誘雷点が その極性領域の中央部にある場合, 例えば(b), (d)，(e)，(f)図などでは放電路が枝分れしている ものもあるが，真上に向かうものが多い。

これらの例には, 地上電界の極性の異なった領域に またがって放電路が進展したものはなかった。

ロケット誘雷では打上げ点の地上電界がある程度高 い值に達したときにロケットを発射している。ここで 述べたように，その周辺の地上電界分布と照合する と, それと放電路の進展との相関性が認められる。

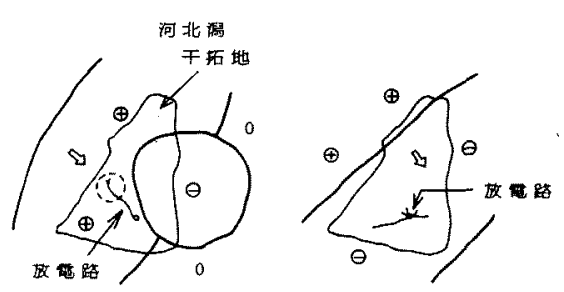

(a) $82-2($ 昭 $57.11,24,18: 30)$ (b) $82-9(8857,12 \cdot 2,6: 20)$

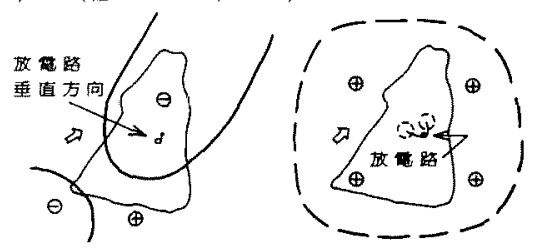

(c) $84-3($ 䠰 $59.12 .1,19: 28$ ) (d) 84-4(昭 $59.12 .1,19: 38)$
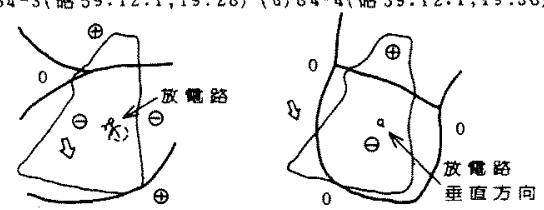

(e) 84-8(昭 59.12.19,0:33)(f) 84-9(昭59.12.19,1:17)
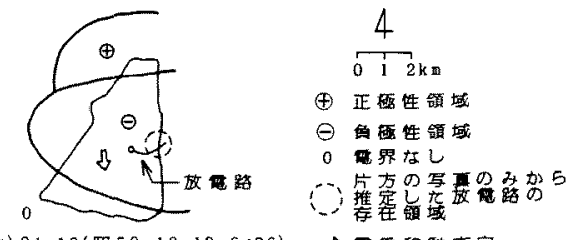

(g) $84-12($ 昭 $59,12,19,6: 26)$

$\Rightarrow$ 雷梨方向

図 6 地上電界の地域分布とロケット誘雷 放電路の投影図

Fig. 6. Regional distributions of the electric field on the ground and horizontal projection of lightning paths triggered by a rocket-wire method. 


\section{5. 結}

\section{論}

針端コロナ電流の多地点観測加ら地上電界極性の地 域分布を推定する方法を示した。各地点の観測では針 端コロナ電流の時間的変化が得られるにすぎないし かし，日本海側冬季雷のように，雷雲内の電荷配置が ある程度保たれながら移動してくることを前提とすれ ば，3点の観測データから雷雲の移動方向と移動速度 とを推定できる。これを異なった 3 点ごとのデータか ら算定したところ，いずれもかなり類似した結果を得 ることができ，この方法が妥当なことが裏づけられ た。このようにして決定した雷雲の移動速度と移動方 向から，作図により電界極性の地上分布が求まる。こ れにより地上電界の状沅がよくわかるようになり，雷 雲の大きさもおよそ推定できる。この方法では，わず かな地点の観測によりかなり広範囲な地域の電界が推 定できる。

この応用例として, 得られた地上電界極性の地域分 布とロケット誘雷の放電路の立体解析との関連性を検 討した。その結果, ロケット誘雷による放電路は地上 電界の誘雷点を含む同一極性領域の中央部に向かう傾 向が諗められた。自然の落雷の場合にも，放電路が横 に長く延び出す例が幾つか観測されており，本推定法 をより㕕域での多地点観測に道用すればその原因にせ
まることができ，また有効な落雷警報を提供できるも のと推察される。

終りに，本研究の一部は科学研究費補助金一般研究 (C)「課題番号 62550200」を受けたことを付記する。 また，名古屋大学工学部堀井憲爾教授を代表とする ロケット誘雷実験グループ各位の有益なご討論に樑詯. いたします。卒業研究として実験に参加された名古屋 大学工学部学生五十住晋一君の御協力に謝意を表し ます。

(昭和63年7月 25 日受付, 平成元年1月17日再受付)

\section{文献}

（1）例元ぱ，大和，他：「雷害事故実態了，電学誌，98，1151 (昭 53-12) 配電線雷害対策専門委買会：「配電線雷害対策」，電気拹同 研究, 40, No. 6 (昭 60-2)

（2）势野，他：「冬季雷雲の規模からみた口ケット誘雷の特徽」， 電学論 $B, 106,685$ (昭 61-8)

（3）鬼頭：「雷電界, 架間電荷の観測」，昭 60 電気学会全大， S. 13-4

(4) R. H. Golde: Lightning I, p. 440 (1977) Academic Press

（5）東山，他：「雷需下の針端コロ十電流特性とそれによる雷雲 接近の㮔知」, 電学論 A, 99,441 (昭 54-9)

（6）堀井・宮地：「ロケットに上る雷放電卜リガの実験」, 電学 誌, 98, 1160 (昭 53-12)

（7）池田：「夏季雷々冬季雷」，電気、評論，66，650(昭 56-7)

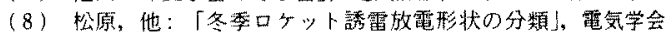
放電・高電圧合同研資，ED-85-71：HV-85-22(昭60) 